RASĀYAN J. Chem.

Vol. 13 | No. 3 |1871-1877| July - September | 2020 ISSN: 0974-1496 | e-ISSN: 0976-0083 | CODEN: RJCABP http://www.rasayanjournal.com http://www.rasayanjournal.co.in

\title{
EVALUATION AND ESTIMATION OF DRINKING WATER QUALITY INDEX IN THIRUKKAZHUKUNDRAM BLOCK, TAMIL NADU, INDIA
}

\author{
A. Amuthini Sambhavi ${ }^{1, *}$, K. Nagamani ${ }^{2}$ and B. Gowtham ${ }^{3}$ \\ ${ }^{1}$ Research Scholar, Sathyabama Institute of Science and Technology, \\ Tamil Nadu, Chennai-600119. \\ ${ }^{2}$ Scientist-C, Centre for Remote Sensing and Geo-informatics, \\ Sathyabama Institute of Science and Technology, Tamil Nadu, Chennai-600119. \\ ${ }^{3}$ Head of the Department and Assistant Professor, Department of Geology, \\ Presidency College, Tamil Nadu, Chennai-600005. \\ *E-mail: sambhavi.kabali@gmail.com
}

\begin{abstract}
Evaluation and assessment of drinking water quality index (DWQI) of aquifer water in Thirukkazhukundram block are done in this paper. Thirty groundwater samples from open and Bore wells were collected and analyzed for premonsoon (PRM 2016 August) and post-monsoon (POM 2017 February) physicochemical tests using APHA procedures. DWQI was calculated by giving weightage to $\mathrm{pH}, \mathrm{EC}, \mathrm{TDS}, \mathrm{TH}, \mathrm{Ca}, \mathrm{Mg}, \mathrm{Na}, \mathrm{K}, \mathrm{HCO}_{3}, \mathrm{Cl}, \mathrm{SO}_{4}$.From this DWQI workout, we get to know that during PRM and POM all the places of sample collection are categorized to be fit for the drinking category from medium to excellent. The positive correlation between various ion pairs obtained from SPSS software for PRM and POM major ions respectively is due to chemical weathering, leaching of salts, and anthropogenic factors. Thus, proper planning and management of pollution-free groundwater could be propelled to upgrade the medium category groundwater too.
\end{abstract}

Keywords: Groundwater, Drinking Water Quality Index, Geographic Information System (GIS), Spatial Analysis, Physicochemical Tests.

(C) RASĀYAN. All rights reserved

\section{INTRODUCTION}

Groundwater is a vital resource for millions of people for both drinking and irrigation purposes. In India, most of the population is dependent on groundwater for drinking purposes. Therefore, bundles of researches were carried out concerning groundwater quality. The Water Quality Index is elucidated as a speculation of the conglomerate impact of distinct quality parameters on the net water quality. It is principally classified into two types, they are Physicochemical and biological indices. The Physicochemical indices rely on the values of Physicochemical parameters in a water sample, while biological indices are relevant to the biological facts. The Water quality index synthesizes complex scientific data into an easy fit format with the below merits:

- The water quality index can furnish a means to summarize net water quality context in a communicable mode to the common man.

- It can report to us whether the net quality of water bodies poses a potential threat to innumerable water usage sectors.

- It can point out a victory in the refuge and reformation efforts.

Here, the area under study has its water quality index arrived at the cause of hydro chemical particulars. It is worth for spotting and rating of water filthiness. Its appliance in agricultural practice, industries, municipalities, and rural homes show a ceaseless increase due to the intense hike in the pollution rate. Hence, serious steps must be taken to evaluate pollution to adopt proper measures to maintain and manage potable water standards.

Rasayan J. Chem., 13(3), 1871-1877(2020)

http://dx.doi.org/10.31788/ RJC.2020.1335702 
RASĀYAN J. Chem.

Vol. 13 | No. 3 |1871-1877| July - September | 2020

Around 29,000 million litres/day of wastewater is got from class-I cities and class-II towns. Out of this, about $45 \%$ (about $13000 \mathrm{ml}$ ) is from 35 metro-cities alone as per Central Pollution Control Board's latest report. The treatment capacity accounts for about 7000 million litres/day while the accumulation system accounts for about $30 \%$ of the wastewater alone through the conduit pathway. Wastewater generation, collection, and remedial measure thereby have a large gap in between. A nearby surface water body or accumulated cesspools which are a good procreation ground for mosquitoes and subsurface water contamination serve as the storehouse for a major part of un-collected and un-treated wastewater. Periodic and proper maintenance of conventional septic tanks and other small budget sanitation facilities must be checked for sure. The subsurface water filthiness complication in divergent parts of the country has become so dreadful that unless hasty and prompt strategic steps as remedial measures are taken, groundwater resources may be harmed. Urban, industrial or agricultural activities threaten land and pollute groundwater. Groundwater pollution is caused by industrial effluents, landfills, underground chemical inputs and harmful wastes forming concentrated large scale easily notable pollution sources which could be regulated compared to the problematic diffuse pollution sources like percolation of agronomics and animal wastes, underground ejections from washrooms and drainage tanks and invasion of infected urban run-off and sewage where sewerage does not survive or nonexistent. These pervaded sources pollute aquifers. Controlling and treating of the diffuse source contaminated aquifers is a tedious task. Integrated land use and water management form the wholesome remedy to dispersed factors of filthiness. Using the weighted arithmetic index method, the present study is done. Similar studies also have been done (Table-1). ${ }^{1-4}$

Table-1: Land-use Activities and their Groundwater Quality Risks

\begin{tabular}{|c|c|}
\hline $\begin{array}{l}\text { Land Use Activities potential to groundwater } \\
\text { foulness } \\
\text { Uptown }\end{array}$ & $\begin{array}{l}\text { - Un-sewered sanitation } \\
\text { - Dispense of sewage from realm and tributary } \\
\text { - Sewage oxidation ponds } \\
\text { - Trench detriment, wreckage trashing, } \\
\text { Landfill liquid percolations } \\
\text { - Road and urban overflow, aerial fall out }\end{array}$ \\
\hline Technical and Business aligned & $\begin{array}{l}\text { - Process water, effluent lagoon, etc. } \\
\text { - The Pervasion of seepages from settlement sector and } \\
\text { creek } \\
\text { - Tank and pipeline seepages and unforeseen } \\
\text { Pour outs } \\
\text { - Well pollutant expulsions } \\
\text { - Aerial fall out } \\
\text { - Junkyard trashing and solid ravages and dangerous } \\
\text { ruins } \\
\text { - Substandard household management } \\
\text { - Dismissal and percolations during } \\
\text { stuff management }\end{array}$ \\
\hline Tunnelling & $\begin{array}{l}\text { - Drainage release from mines } \\
\text { - Process water, slurry lagoons } \\
\text { - Solid mine tailings } \\
\text { - Spillages of Oilfield at the group } \\
\text { congregation stations }\end{array}$ \\
\hline Countryside & $\begin{array}{l}\text { - Agrochemicals aid in the cultivation } \\
\text { - Wastewater irrigation } \\
\text { - Litho unit Salinizations } \\
\text { - Livestock rearing }\end{array}$ \\
\hline Seaside zones & - Saltwater intervention \\
\hline
\end{tabular}

\section{EXPERIMENTAL}

\section{Study Area}

In arid and semi-arid areas, the potential use of groundwater for drinking and agricultural projects is threatened by the decline of water quality due to physical and anthropogenic characteristics. The ideal 
RASĀYAN J. Chem.

Vol. 13 | No. 3 |1871-1877| July - September | 2020

quantity and standard quality of water are one of the essential needs for the survival of mankind on Earth, but the maintenance of the acceptable quality of water is a challenge in the sector of water resources management. The water quality assessment is based on several parameters such as physical, chemical, and biological characterization.

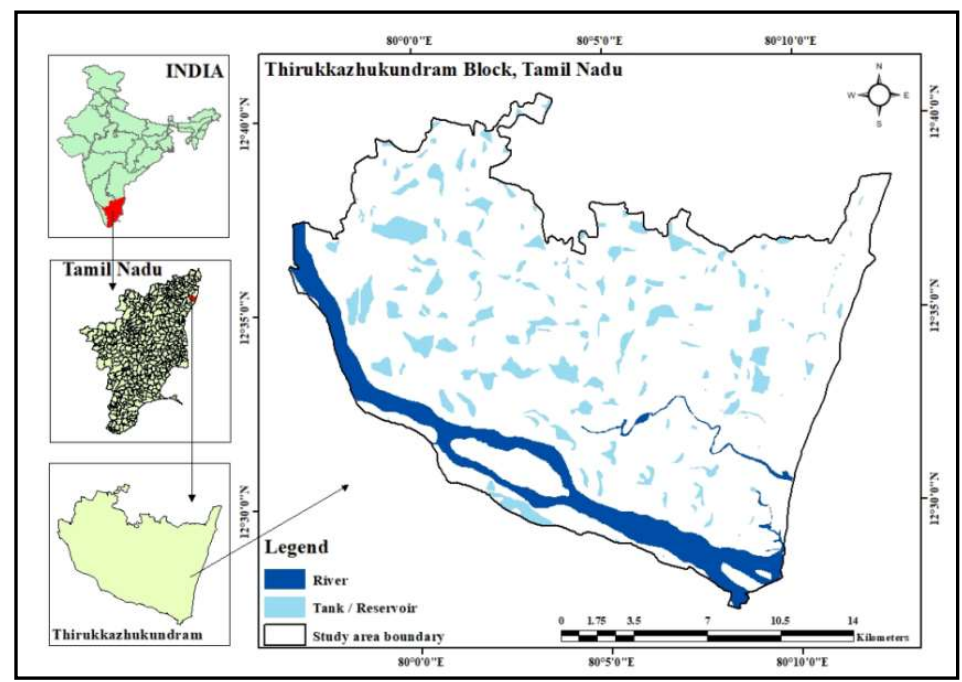

Fig.-1: Location Map of Thirukkazhukundram Block

Water quality index (WQI) is defined as a rating reflecting the composite influence of different water quality parameters. WQI is one of the most effective tools to interconnect information on the quality of any water body. In drinking water quality assessment, the decision-making based on water quality data is a key issue because the number of parameters compromises its quality. There has been considerable progress particularly based on the principle of WQI using slightly modified concepts. The Geographic Information System is a very impressive tool for groundwater management and pollution study since it offers an overlay mapping techniques to identify an association between them. There are several literature reported for the management of water quality mapping analysis using the GIS platform. The appearance of satellite technology and geographical information system (GIS) has made it very easy to map the sampling area. GIS has a wide application in water quality mapping using which informative and userfriendly maps can be obtained. The objective of the study is to determine the class of all thirty samples includes bore well and open well using the weighted arithmetic index method. In this method, the eleven important parameters such as $\mathrm{pH}$, Electrical Conductivity (EC), Total Dissolved Solids (TDS), Total Hardness (TH), Calcium $\left(\mathrm{Ca}^{2+}\right)$, Magnesium $\left(\mathrm{Mg}^{2+}\right)$, Sodium $\left(\mathrm{Na}^{+}\right)$, Potassium $\left(\mathrm{K}^{+}\right)$, Bicarbonate $\left(\mathrm{HCO}_{3}^{-}\right)$, Chlorides $\left(\mathrm{Cl}^{-}\right)$, Sulphates $\left(\mathrm{SO}_{4}^{-}\right)$were taken for the assessment. The drinking water quality index (DWQI) was developed for the study area.

\section{Detection Method}

A semi-critical area (CGWB, 2010) covering $352.82 \mathrm{~km}^{2}$, coastal Thirukkazhukundram Block of Kanchipuram district, Tamil Nadu posed at the south part of India is enveloped by Bay of Bengal in the East, Maduranthagam in the West, Kattankolathur, Thiruporur in the North and Lattur in the South located between Latitudes $12^{\circ} 00^{\prime \prime} \mathrm{N}$ and $12^{\circ} 10^{\prime \prime} \mathrm{N}$ and Longitudes $80^{\circ} 00^{\prime \prime} \mathrm{E}$ and $80^{\circ} 10^{\prime \prime} \mathrm{E}$ (Fig.1). ${ }^{11}$ Agriculture is the main livelihood of the majority of people in this district. Rice is the major crop grown throughout all over the district. Madurantakam, Cheyyur, and Thirukkazhukundram Block are major producers of rice in this district. A total of 30 numbers of groundwater samples were collected during pre-monsoon (2016 August) and post-monsoon (2017 February) from various locations of the study area as per the standard protocol prescribed by APHA (1995). ${ }^{12}$ The groundwater sample location points were marked by using a global positioning system (GPS). In this study, eleven physicochemical 
RASĀYAN J. Chem.

Vol. 13 | No. 3 |1871-1877| July - September | 2020

parameters were analyzed using the APHA procedure. The values were compared with the World Health Organization, WHO, (2011) (Table-2). ${ }^{7}$

For discerning, APHA procedure ${ }^{8-10}$ based tested water specimens of Thirukkazhukundram Block under surface water characteristics and its appropriateness for intake utility, Water Quality Index is a salient criterion. ${ }^{5,6}$ For working out the water quality index (WQI), a weighted arithmetic quality means strategy has been put to use. Abided essential three steps are run over below. ${ }^{4,7}$ (Water quality parameters with their std value and unit wt. std values are given in Table-2).

First step primarily plans for each of the eleven variables to be allocated a weight $\left(\mathrm{w}_{\mathrm{i}}\right)$ as per its respective influence in the wholesome characteristic of water for intake objective. The parameter with a paramount consequence in water quality computation has been tagged a maximum weight of ' 5 ' and the one with less consequence has been tagged a minimum weight of ' 1 '. The second step progresses with the corresponding weight specification by:

$$
\mathrm{W}_{\mathrm{i}}=\left.\mathrm{w}_{\mathrm{i}}\right|_{\mathrm{i}=1} ^{\mathrm{n}} \mathrm{W}_{\mathrm{i}}
$$

Where, $\mathrm{Wi}=$ relative weight, wi $=$ Weight of each variable, $\mathrm{n}=$ the number of variables. The third step ends up by allocating a quality rating scale (qi) for each parameter by dividing its concentration in each water specimen by its respective standard as per WHO standards and the result taken as the product of 100:

$$
q i=(\mathrm{Ci} / \mathrm{Si}) \times 100
$$

Where, $\mathrm{qi}=$ quality rating, $\mathrm{Ci}=$ concentration of each hydro chemical parameter in each water specimen in $\mathrm{mg} / \mathrm{l}, \mathrm{Si}=\mathrm{Sub}$-index of the ith parameter for each hydro-chemical parameter in $\mathrm{mg} / \mathrm{l}$.

$$
\mathrm{SI}_{\mathrm{i}}=\mathrm{W}_{\mathrm{i}} \times \mathrm{q}_{\mathrm{i}}
$$

For arriving at WQI, SI was enumerated for each parameter. Final WQI can be met through the summation of each sample SI live values by the relation:

$$
\mathrm{WQI}=\sum_{\mathrm{i}=1}^{\mathrm{n}} \mathrm{Si}
$$

\section{Spatial Distribution Method}

The DWQI results were imported in Arc Map (10.0) and it is integrated with spatial data. All the data were entered into a spatial database and spatial variations of the results were developed using the Inverse Distance Weighted (IDW) method. The spatial distribution map was prepared using the IDW interpolation method. Though there are several spatial modelling techniques available concerning the application in GIS, this method is utilized because of the interpolated value predicted upon their distance from the output point, thereby generating a surface grid as well as thematic isolines. In the IDW method, the weightage is the function of the distance between the point of interest and sampling station.

Table-2: Water Quality Parameters with their Std. Value and Unit wt. Std Values are in $\mathrm{mg} / \mathrm{l}$ excluding $\mathrm{pH}$ and EC.

\begin{tabular}{c|c|c|c}
\hline S. No. & Parameters & WHO(2011) Std & Unit Weight \\
\hline 1. & $\mathrm{pH}$ & 8.5 & 0.135 \\
\hline 2. & $\mathrm{EC}(\mu \mathrm{g})$ & 1500 & 0.135 \\
\hline 3. & $\mathrm{TDS}$ & 1500 & 0.135 \\
\hline 4. & $\mathrm{TH}$ & 500 & 0.135 \\
\hline 5. & $\mathrm{Ca}$ & 200 & 0.081 \\
\hline 6. & $\mathrm{Mg}$ & 50 & 0.054 \\
\hline 7. & $\mathrm{Na}$ & 200 & 0.054 \\
\hline 8. & $\mathrm{~K}$ & 12 & 0.054 \\
\hline 9. & $\mathrm{Cl}$ & 600 & 0.108 \\
\hline 10. & $\mathrm{SO}_{4}$ & 400 & 0.108 \\
\hline 11. & $\mathrm{HCO}_{3}$ & 500 & 0.027 \\
\hline
\end{tabular}


RASĀYAN J. Chem.

Vol. 13 | No. 3 |1871-1877| July - September | 2020

\section{RESULTS AND DISCUSSION}

The PRM and POM analytical summary of the scrutinized variables in Table-3 shows that $\mathrm{pH}$ stretches from 7.2 to 8.2 and ranges from 7.03 to 8.09 respectively.EC values stretch from 616.9 to $2766 \mu$ s during PRM and during POM, the limit is from 100.8 to $1219 \mu$ s.PRM TDS limitation is from 438.03 to $1964.20 \mathrm{mg} / \mathrm{l}$ and POM TDS limitation is from 71.56 to $865.78 \mathrm{mg} / \mathrm{l}$.TH varies from 134.5 to $890.1 \mathrm{mg} / \mathrm{l}$ for PRM and from 25.5 to $344 \mathrm{mg} / 1$ for POM.PRM Ca varies from 30.4 to $201 \mathrm{mg} / \mathrm{l}$ and POM Ca varies between 7.84 and $86.2 \mathrm{mg} / 1 . \mathrm{PRM} \mathrm{Mg}$ has its variation from 11.2 to $104 \mathrm{mg} / \mathrm{l}$ and for POM Mg, it is from 1.2 to $32 \mathrm{mg} / 1$. PRM Na varies from 43.2 to $265 \mathrm{mg} / 1$ and from 10.2 to $136 \mathrm{mg} / 1$ for POM Na. PRM K limits between 8.2 and $92 \mathrm{mg} / 1$ and between 1.23 and $26.24 \mathrm{mg} / 1$ for POM K.

Table-3: Analytical Summary of the Examined Variables (PRM and POM) Values in mg/l excluding pH

\begin{tabular}{c|c|c|c|c|c|c|c|c|c}
\hline \multirow{2}{*}{ S. No. } & \multirow{2}{*}{ Variables } & \multicolumn{2}{|c|}{ Minimum } & \multicolumn{2}{c|}{ Maximum } & \multicolumn{2}{c|}{ Mean } & \multicolumn{2}{c}{ Standard Deviation } \\
\cline { 3 - 10 } & & PRM & POM & PRM & POM & PRM & POM & PRM & POM \\
\hline 1 & $\mathrm{pH}$ & 7.2 & 7.03 & 8.2 & 8.09 & 7.71 & 7.56 & 0.57 & 0.3 \\
\hline 2 & $\mathrm{EC}$ & 616.9 & 100.8 & 2766 & 1219 & 1311 & 525.1 & 91.41 & 41.17 \\
\hline 3 & $\mathrm{TDS}$ & 438.03 & 71.56 & 1964.20 & 865.78 & 930.63 & 372.81 & 64.90 & 29.23 \\
\hline 4 & $\mathrm{TH}$ & 134.5 & 25.5 & 890.1 & 344 & 379.1 & 144 & 36.73 & 17.9 \\
\hline 5 & $\mathrm{Ca}$ & 30.4 & 7.84 & 201 & 86.2 & 87.1 & 34.8 & 12.7 & 6.9 \\
\hline 6 & $\mathrm{Mg}$ & 11.2 & 1.2 & 104 & 32 & 39.3 & 14 & 1.21 & 0.2 \\
\hline 7 & $\mathrm{Na}$ & 43.2 & 10.2 & 265 & 136 & 129 & 55 & 7.09 & 2.08 \\
\hline 8 & $\mathrm{~K}$ & 8.2 & 1.23 & 92 & 26.24 & 30 & 11.53 & 5.7 & 1.99 \\
\hline 9 & $\mathrm{Cl}$ & 60 & 10.2 & 475 & 175 & 193 & 81.6 & 17 & 4.82 \\
\hline 10 & $\mathrm{SO}_{4}$ & 38.4 & 6.52 & 386 & 135 & 136 & 40.7 & 1.42 & 3.66 \\
\hline 11 & $\mathrm{HCO}_{3}$ & 149 & 30.1 & 607 & 291 & 311 & 131 & 68.4 & 7.71 \\
\hline
\end{tabular}

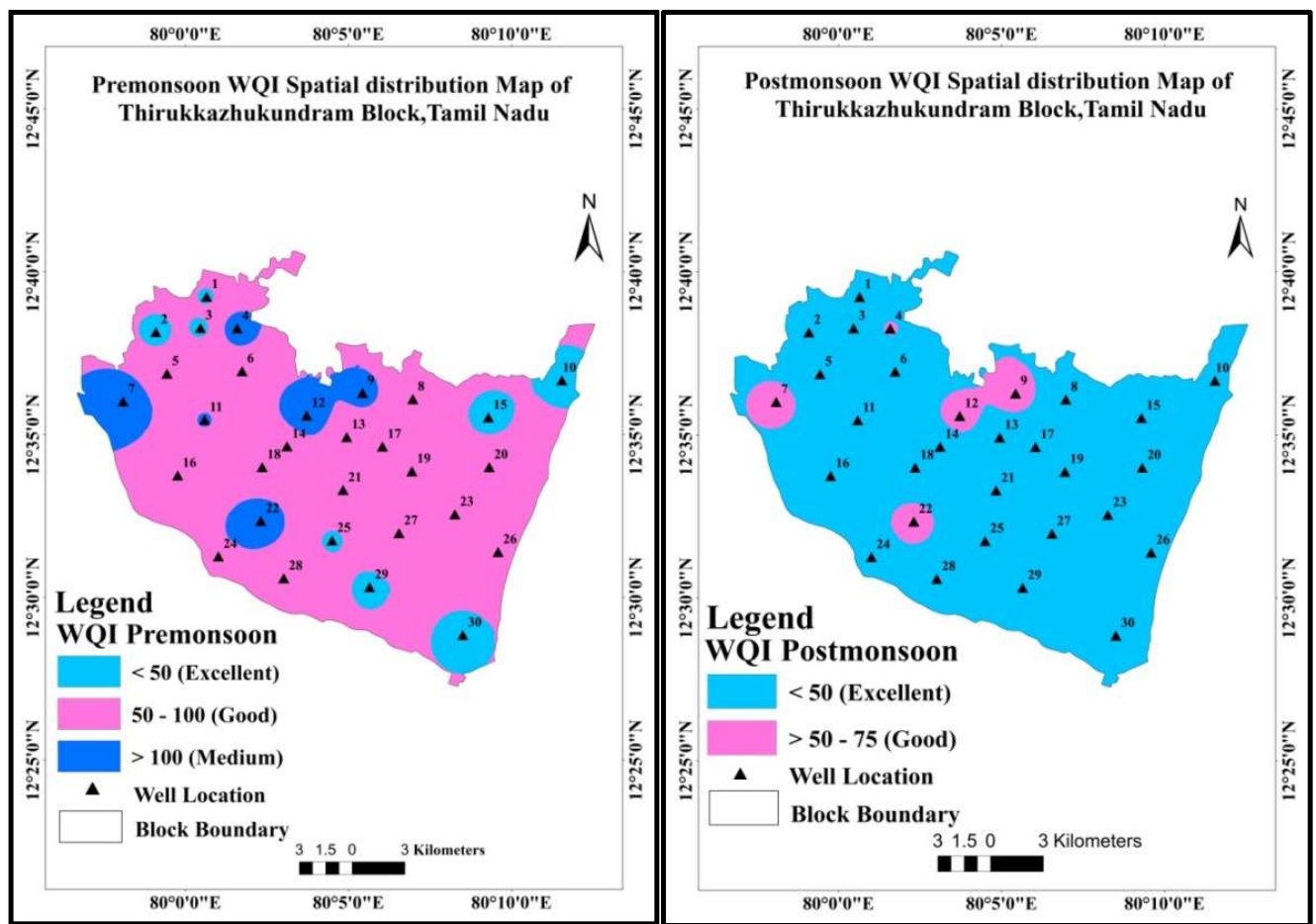

Fig.-2: Pre-monsoon WQI Spatial Distribution Fig.-3: Post-monsoon WQI Spatial Distribution

$\mathrm{Cl}$ fluctuates from 60 to $475 \mathrm{mg} / 1$ during PRM and from 10.2 to 175 during $\mathrm{POM}_{\mathrm{SO}} \mathrm{S}_{4}$ varies between 38.4 and $386 \mathrm{mg} / \mathrm{l}$ for PRM and varies between 6.52 and $135 \mathrm{mg} / 1$ for $\mathrm{POM}_{\mathrm{HCO}} \mathrm{HCaries}_{3}$ from 149 to $607 \mathrm{mg} / 1$ for PRM and from 30.1 to $291 \mathrm{mg} / 1$ for POM. 
RASĀYAN J. Chem.

Vol. 13 | No. 3 |1871-1877| July - September | 2020

Table-4: NSF WQI

\begin{tabular}{c|c|c|c|c|c}
\hline \multirow{2}{*}{ WQI } & Water Quality & \multicolumn{2}{|c|}{ Sample Nos } & \multicolumn{2}{c}{ Sample \% } \\
\cline { 3 - 6 } Value & Rating & PRM & POM & PRM & POM \\
\hline$<50$ & Excellent & 8 & 25 & 27 & 83 \\
\hline $50-100$ & Good & 16 & 5 & 53 & 17 \\
\hline$>100$ & Medium & 6 & - & 20 & - \\
\hline
\end{tabular}

WQI of the parameters varies from 39.67 to 153.3 for PRM and from 20.86to 68.3 for POM.WQI Spatial distribution maps for PRM and POM using ArcGIS 10.0 are shown in fig.2 and fig.3 samples get classified as excellent during PRM. Nenmeli, Thirumani, Alagusamudram, Mamallapuram, Kadambadi, Pandur, Nallathur, Voyalur, are the locations falling under excellent category (Table-4). Sixteen locations graded under good category WQI during PRM are Mosivakkam, Thazhambedu, Kuzhipanthandalam, Igai, Navalur, Salur, Pattikadu, Thathalur, Amaipakkam, Kunnathur, Veerapuram, Neikuppi, Vilagam, Sadurangpatnam, Lattur and Irumbilicheri. 6 places fall under the medium category WQI during PRM. These PRM places of the medium category are Keerapakkam, Manapakkam, Pulikundram, Ponvilayanthakalathur, Thirukazhukundram, Kilapakkam. During POM, 5 good category WQI places are Keerapakkam, Manapakkam, Pulikundram, Thirukazhukundram, and Kilapakkam and the rest of the twenty-five locations come under excellent category WQI.

Table-5: Pre-monsoon Correlation Matrix Analysis Result of the Groundwater Quality Parameters in the Study Area

\begin{tabular}{c|c|c|c|c|c|c|c|c|c|c}
\hline & $\mathrm{pH}$ & $\mathrm{EC}$ & $\mathrm{TDS}$ & $\mathrm{Ca}$ & $\mathrm{Mg}$ & $\mathrm{Na}$ & $\mathrm{K}$ & $\mathrm{HCO}_{3}$ & $\mathrm{Cl}$ & $\mathrm{SO}_{4}$ \\
\hline $\mathrm{pH}$ & 1 & & & & & & & & & \\
\hline $\mathrm{EC}$ & 0.04492 & 1 & & & & & & & & \\
\hline $\mathrm{TDS}$ & 0.04492 & 1 & 1 & & & & & & & \\
\hline $\mathrm{Ca}$ & 0.08309 & 0.9608 & 0.9608 & 1 & & & & & & \\
\hline $\mathrm{Mg}$ & 0.09187 & 0.90202 & 0.90202 & 0.82424 & 1 & & & & & \\
\hline $\mathrm{Na}$ & 0.03627 & 0.926 & 0.926 & 0.8967 & 0.82279 & 1 & & & & \\
\hline $\mathrm{K}$ & 0.00185 & 0.90263 & 0.90263 & 0.83424 & 0.78235 & 0.82422 & 1 & & & \\
\hline $\mathrm{HCO} 3$ & 0.08061 & 0.90604 & 0.90604 & 0.88895 & 0.85104 & 0.77198 & 0.77201 & 1 & & \\
\hline $\mathrm{Cl}$ & 0.00577 & 0.97162 & 0.97162 & 0.91421 & 0.8706 & 0.90884 & 0.8872 & 0.79704 & 1 & \\
\hline $\mathrm{SO} 4$ & 0.01293 & 0.93976 & 0.93976 & 0.87153 & 0.79823 & 0.84913 & 0.89422 & 0.75215 & 0.95797 & 1 \\
\hline
\end{tabular}

Table-6: Post-monsoon Correlation Matrix Analysis Result of the Groundwater Quality Parameters in the StudyArea

\begin{tabular}{c|c|c|c|c|c|c|c|c|c|c}
\hline & $\mathrm{pH}$ & $\mathrm{EC}$ & $\mathrm{TDS}$ & $\mathrm{Ca}$ & $\mathrm{Mg}$ & $\mathrm{Na}$ & $\mathrm{K}$ & $\mathrm{HCO}_{3}$ & $\mathrm{Cl}$ & $\mathrm{SO}_{4}$ \\
\hline $\mathrm{pH}$ & 1 & & & & & & & & & \\
\hline $\mathrm{EC}$ & 0.0430 & 1 & & & & & & & & \\
\hline $\mathrm{TDS}$ & 0.0430 & 1 & 1 & & & & & & & \\
\hline $\mathrm{Ca}$ & 0.0837 & 0.9146 & 0.9146 & 1 & & & & & & \\
\hline $\mathrm{Mg}$ & -0.050 & 0.9023 & 0.9023 & 0.8435 & 1 & & & & & \\
\hline $\mathrm{Na}$ & 0.0090 & 0.9664 & 0.9664 & 0.8093 & 0.8446 & 1 & & & & \\
\hline $\mathrm{K}$ & 0.0116 & 0.9409 & 0.9409 & 0.8515 & 0.86134 & 0.8875 & 1 & & & \\
\hline $\mathrm{HCO}_{3}$ & 0.0721 & 0.9842 & 0.9842 & 0.9164 & 0.89644 & 0.9335 & 0.9103 & 1 & & \\
\hline $\mathrm{Cl}$ & -0.013 & 0.9660 & 0.9660 & 0.8556 & 0.86425 & 0.9453 & 0.9256 & 0.9225 & 1 & \\
\hline $\mathrm{SO}_{4}$ & 0.1235 & 0.9549 & 0.9549 & 0.8749 & 0.82254 & 0.9179 & 0.9097 & 0.9349 & 0.8784 & 1 \\
\hline
\end{tabular}

Values in red are different from 0 with a significance level alpha $=0.5$

Accordingly, the result of spatial distribution found that groundwater in most of the parts of Thirukkazhukundram block is well suitable for drinking purposes. Some part of the study area shows a medium category in pre-monsoon due to high total hardness and marginally high value of calcium prescribed by the permissible limit of WHO (2011). The maximum value of TH has been recorded as $890.1 \mathrm{mg} / 1$ in the study area. Water with hardness greater than $200 \mathrm{mg} / \mathrm{l}$ is considered poor in most regions of the province and water with hardness greater than $500 \mathrm{mg} / \mathrm{l}$ is normally considered unacceptable for domestic purposes. Water hardness in most groundwater is naturally occurring from weathering of limestone, sedimentary rock, and calcium bearing minerals. Hardness can also occur locally in groundwater from the excessive application of lime to the soil in agricultural areas. The relationship 
RASĀYAN J. Chem.

Vol. 13 | No. 3 |1871-1877| July - September | 2020

between the two parameters is well interpreted using the correlation coefficient. It is an easy means by which behaviour of one parameter prediction by another parameter is well exhibited. In the pre and postmonsoon samples good correlation exists between $\mathrm{EC}$, TDS, $\mathrm{Ca}, \mathrm{Mg}, \mathrm{Na}, \mathrm{K}, \mathrm{HCO}_{3}, \mathrm{Cl}, \mathrm{SO}_{4}$, with other ions as marked in red. Chemical weathering accounts for good correlation of $\mathrm{HCO}_{3}$ with $\mathrm{Ca}, \mathrm{Na}$, and $\mathrm{Cl}$. Leaching of salts, and anthropogenic factors contribute mainly for a good correlation of $\mathrm{Cl}$ with $\mathrm{Ca}, \mathrm{Na}$ and $\mathrm{K}_{\mathrm{SO}} \mathrm{S}_{4}$ shows a good positive correlation with $\mathrm{Na}$, indicating the leaching of marcasite present in this region.

\section{CONCLUSION}

This study, on account of minimizing the uncertainty and inexactness in resolution arriving, with the aid of the adopted water quality index (WQI) system using 11 variables in the research domain for subsurface water, for PRM, has 8 samples sorted under the excellent category, 16 samples under good and 6 samples under the medium category.Viz.27\%, 53\% and 20\% respectively. Hence, PRM excellent category covers Nenmeli, Thirumani, Alagusamudram, Mamallapuram, Kadambadi, Pandur, Nallathur, Voyalur whereas during POM, 5 specimens are sorted under good group and rest of the 25 specimens are graded as excellent category.viz.17\%, and 83\% respectively. Thereby, locations covered during POM are Keerapakkam, Manapakkam, Pulikundram, Thirukazhukundram, and Kilapakkam and the rest of the 25 stands for excellent and the highlight is that all the villages of sample collection are categorized to be fit for drinking category from medium to excellent. Chemical weathering, leaching of salts, and anthropogenic factors stand as proof to the positive correlation that arrived with the ions.

\section{ACKNOWLEDGMENT}

The Research Scholar gratefully acknowledges the support extended by Dr.B.Gowtham, Head of the Department and Assistant professor of Geology, Presidency College, Chennai throughout the work and renders sincere thanks to Guide, Dr.K.Nagamani, Scientist- 'C,' Centre for GIS and Remote Sensing, Sathyabama Institute of Science and Technology, Chennai for her warm guidance.

\section{REFERENCES}

1. A. Kumar, and A. Dua, Global Journal of Environmental Sciences, 8(1), 49(2009), DOI:10.4314/GJES.V8I1.50824

2. N.S. Magesh, S. Krishnakumar, N. Chandrasekar, J.P. Soundranayagam, Arabian Journal of Geosciences, 6(11), 4179(2012), DOI:10.1007/s12517-012-0673-8

3. G. Maheswaran, and K. Elangovan, Nature Environment and Pollution Technology, 13(3), 547(2014).

4. S. Varol, and A. Davraz, Environmental Earth Sciences, 73(4), 1725(2015), DOI:10.1007/s12665014-3531-z

5. S.M. Sadat-Noori, K. Ebrahimi, and A.M. Liaghat, Environmental Earth Sciences, 71(9), 3827(2014), DOI: 10.1007/s12665-013-2770-8

6. WHO Guidelines for Drinking-water Quality, fourth ed. World Health Organization, WHO (2011)

7. A.M. Shala Abazi, B. H. Durmishi, F. S. Sallaku, H. S. Ã tadraku, O. B. Fetoshi, P. H. Ymeri, and P. S. BytyÃßI, Rasayan Journal of Chemistry, 13(1), 146(2020), DOI:10.31788/RJC.2020.1315344

8. K. Boudeffa, F. Fekrache And N. Bouchareb,Rasayan Journal of Chemistry, 13(1), 168(2020), DOI: $10.31788 /$ Rjc.2020.1315255

9. V. Dhilleswara Rao1, M.V. Subba Rao and M.P.S.Murali Krishna, Rasayan Journal of Chemistry, 12(4), 1828(2019), DOI: 10.31788/RJC.2019.1245394

10. Ashwani Kumar Sonkar and Aarif Jamal, Rasayan Journal of Chemistry, 12(2), 608(2019), DOI: 10.31788/RJC.2019.1225105

11. Annual report, Ministry of Water Resources, Government of India, CGWB (Central Ground Water Board) (2010)

12. AMPHA. Standard Methods for the Examination of Water and Waste Water, $19^{\text {th }}$ Edition, American Public Health Association, Washington DC, APHA. (1995)

[RJC-5702/2020] 